\title{
Treatment of the interaction between polymers and liquids in terms of the linear free energies concept
}

\author{
R.Makitra, I.Yevchuk, R.Musiy \\ Department of Physico-Chemistry Lytvynenko Institute \\ of Physico-Organic Chemistry NAS of Ukraine, \\ 3a Naukova Str. UA 79053 Lviv, Ukraine
}

Received July, 6, 2005, in final form October 17, 2005

\begin{abstract}
The existing theories of interaction between polymers and liquids don't reveal satisfactory relation between liquid physico-chemical properties and the degree of swelling of polymer in polymer-liquid system. We suggested the linear sixparametric equation, which takes into account both liquid capability of specific and nonspecific solvation and its cohesion energy and molar volume. This equation appears to be fit for treating the data within the processes such as: diffusion of liquids through the thin films, dissolution of polymers, swelling and extraction of coals.
\end{abstract}

Key words: multiparametric equation, correlation coefficient, organic liquid, polymer, solvation, the degree of swelling

PACS: $61.25 . \mathrm{Hq}, 61.82 . \mathrm{Pv}, 82.35 . \mathrm{Lr}$

The character of the interaction between polymers and organic liquids defines the degree of permeability and adsorbtion of the latter and hence the swelling of polymers. It causes changes in the structure of polymers, deterioration of their mechanical properties and finally their destruction. However, the entire compatibility of liquid and polymer phases may be necessary in the technological process of plastification of polymers. On the other hand, the limited penetration of liquids and their diffusion into polymer films find a wide application in different membrane technologies. Finally, the complete dissolution of polymers in the solvents forms the basis for obtaining the glues, lubricants, etc. That is why investigations of these processes which initially had only theoretical significance, have attracted a growing interest for the last decades.

However, the issue of interaction in the polymer-solvent systems has not been developed sufficiently (especially depending on the properties of the solvent). Most investigations are based on conventional Hildebrand theory of regular solutions and its Flory and Huggins application to the processes of swelling of polymers. According 
to this approach the degree of swelling (DS) depends on Hildebrand parameter of solubility of the solvent:

$$
\delta=\frac{\Delta H_{\mathrm{vap}}-R T}{V_{\mathrm{M}}},
$$

where $\Delta H_{\text {vap }}$ is the evaporation heat of the solvent, $V_{\mathrm{M}}$ is its molar volume.

Plotting the dependences DS vs $\delta$ or DS vs $\delta^{2}$ we obtain parabolic curves; the maximum of swelling is observed in the solvents, $\delta$ of which is close to the parameter of solubility of polymers, exactly, of their links between places of crosslinking of polymer chains. It is caused by the character of the relationship, accepted by Hildebrand and Scatchard $[2,3]$, according to which in the case of two liquids mixing with the dominant intermolecular dispersion forces only, minimum of energy consumptions for an even distribution are observed at the equality of $\delta$ parameters of components in a system:

$$
\Delta H_{\text {mix }}=v_{1} v_{2}\left(\delta_{1}-\delta_{2}\right)^{2}
$$

where $v_{1}$ and $v_{2}$ are the molar parts of components.

Besides dispersion forces, marked contribution to the process of mixing of liquids (including polymers) is done by other forms of interaction, which results in significant deviations from theoretical parabolic relation. The maximum on the curve is shifted for different homologous series. Thus, Errede [4] confirmed the shift of the maximum from 7.3 for ethers to 9.0 for ketones and 9.5 for aromatic solvents. Moreover, the data for many solvents cannot be put onto the suggested curve. Obviously, it does not permit to predict DS of polymers in noninvestigated solvents based on the derived curves. The agreement of the experimental results with theoretic relationships by introducing the empiric parameter $(\chi)$, which takes into account the other forms of interaction, failed $[5,6]$. Therefore, new attempts were made with the purpose to relate DS of polymers with other properties of solvents. However, all of the relationships derived were found to be nonadequate. Thus, the DS description of polymers using the molar volume of a solvent $-V_{\mathrm{M}}$ (the larger is the size of the molecule of the liquid the more difficult it is for the molecule to penetrate into the structure of polymer) appears to be fit for separated groups of solvents: aromatic compounds, alcohols, esters etc. (with a number of exceptions though) [7]. Similarly, the attempt to characterize DS using the so-called Reichardt parameter of polarity $\mathrm{E}_{T}$ [8](i.e., capability of electrophilic solvation) - is limited to separated groups of solvents. The attempt to summarize the experimental data on DS of peptide polymers in a wide range of solvents using the capability of donor-acceptor interaction, namely Gutman donor and acceptor numbers (DN and AN), as well as to combine them has failed due to the complex and multifactor character of the process of interaction between polymer and solvent.

At the same time, in the chemistry of solutions over 40 years, the effect of solvents on such characteristics of dissolved substances as spectral frequency, signal shifts in NMR-spectra or, especially, reaction constants, was confirmed in terms of linear free energies concept (LFEC). According to this principle, the change of free energy of dissolved substance is determined as a sum of energetic changes caused by 
independent solvation processes:

$$
\Delta G=\sum \Delta g_{i}
$$

According to this approach U. Mayer suggested to take into account the effects of specific and nonspecific solvation while considering the solvation of compounds as well as the energy consumption in forming the cavities in the liquid phase [9]. In practice, the treatment of the experimental data was performed by Koppel, Palm and coauthors. They used the expression as follows:

$$
\lg X=a_{0}+a_{1} \frac{n^{2}-1}{n^{2}+2}+a_{2} \frac{\epsilon-1}{2 \epsilon+1}+a_{3} \mathrm{~B}+a_{4} \mathrm{E}_{T},
$$

where $X$ is the determined property (i.e., reaction constant, spectral shift etc.), $a_{i}$ are the derived coefficients reflecting the effect of separated solvation factors on $X, a_{0}$ is $\lg X$ in an ideal phase (without interaction); $n$ is the refractive index and $\epsilon$ is permittivity of liquid, which determine its polarity and polarizability and are responsible for nonspecific solvation; $\mathrm{B}$ is the Palm basicity and $\mathrm{E}_{T}$ is the Reichardt electrophilicity of liquid, which characterize its acid-base interaction with substrate (specific solvation).

In the review [11] a successful application of this equation has been described for obtaining an adequate quantitative relation between the properties of solvents and characteristics of dissolved substances for over 100 systems. According to Mayer approach this equation was expanded with the member, which takes into account the energy consumption for forming a cavity in the liquid phase $E_{\text {cavity }}=a \delta^{2}$, (proportional to its cohesion energy $\delta^{2}$ ). We successfully used the above mentioned equation for treating the data regarding gas and solid dissolution in a number of solvents, as well as regarding the distribution of substances between two unmixed phases [11-13]:

$$
\lg X=a_{0}+a_{1} \frac{n^{2}-1}{n^{2}+2}+a_{2} \frac{\epsilon-1}{2 \epsilon+1}+a_{3} \mathrm{~B}+a_{4} \mathrm{E}_{T}+a_{5} \delta^{2} .
$$

Taking into account that polymer is formally considered to be a solid noncrystal phase or a high-viscosity fluid we expected this equation to be fit for obtaining a quantitative dependence of penetration of liquids into polymer structure depending on their physico-chemical characteristics. Indeed, the equation provided a satisfactory relationship between DS of solvents into such polymers as synthetic and natural rubbers [14], polyethylene [16], as well as natural polymer coals [17].

However, in spite of an entirely successful result of this generalization, the data for some solvents do not agree with it and multiple correlation coefficients $R$ of the obtained equations had only moderate value of $0.9-0.97$. Therefore, we expanded the equation with the sixth member $-V_{\mathrm{M}}$, following the logical assumption that the larger is the size of the molecule the more difficult it is to penetrate into the polymer structure taking into account Aminabhavi's and coauthors' point of view concerning the possible value of the molar volume. This fact as well as the change 
of the commonly used expression of DS (the amount of moles of liquid absorbed by $100 \mathrm{~g}$ of polymer instead of the volume parts) make it possible to significantly increase the adequacy of the equation.

Thus, the data on swelling of polyethylene [18], butylrubber [19], a series of coals [20] and so on - were successfully treated. Moreover, the analysis of the equations obtained by successive exclusion of individual terms with determining the value of $R$ for every equation with a smaller number of the terms makes it possible to determine their value and quantitative effect on the value DS. It was found that only two or three factors determine DS in every case depending on the nature of polymer. The other factors are insignificant or have only a correcting effect on DS.

Thus, correlation analysis of the suggested equations enables us to draw conclusions on the character of physico-chemical interaction in the processes of solvation [21]. This equation was found to be fit for treating the data on other processes such as: diffusion of liquids trough the thin films [22], dissolution of polymers [23], swelling and extraction of coals $[24,25]$.

\section{References}

1. Flory P.J., J. Chem. Phys., 1945, 13, 453.

2. Hildebrand J., J. Amer. Chem. Soc., 1929, 51, 66.

3. Scatchard G., Chem. Rev., 1931, 8, 21.

4. Errede L., Macromolecules., 1986, 19, No. 6, 1522.

5. Gee G., Trans. Faraday Soc., 1946, 42, 1333.

6. Bristow G.B., Watson W.F., Trans. Faraday Soc., 1958, 54, No. 11, 1731.

7. Aminabhavi T.M., Harogoppad S.B., Khinnavar R.S., Balundgi R.H. JMS Rev. Macromol. Chem. Phys. C, 1991, 31, No. 4, 433.

8. Jonquieres A., Roizard D., Lochon P., J. Appl. Polym. Sci., 1994, 54, 1673.

9. Mayer U., Monatsh Chemie, 1978, 109, 421.

10. Koppel I.A., Palm V.A. The influence of the solvent on organic reactivity. - In: Advances in Linear Free Energy Relationships, ed. Chapman N.B., Shorter J. Plenum Press, London - New York, 1972, 203-280.

11. Makitra R.G., Pyrig J.M., Politanska T.I., J. Appl.Chem., 1981, 54, 54 (in Russian).

12. Makitra R.G., Pyrig J.M., Oilchemistry, 1980, 20, 145 (in Russian).

13. Makitra R.G., Pyrig J.M., Radiochemisty, 1982, 24, 450 (in Russian).

14. Pyrig J.M., Makitra R.G., Ukr. Chem. J., 1993. 59, 1111 (in Ukrainian).

15. Makitra R.G., Pyrig J.M., Vasyutyn J.M., Ukr. Chem. J., 1999, 65, 64 (in Ukrainian).

16. Makitra R.G., Pyrig J.M., Vasyutyn J.M., Ukr. Chem. J., 1995, 61, 64 (in Ukrainian).

17. Makitra R.G., Pyrig J.M., Chem. of Solid Fuels, 1998, No. 6, 41 (in Ukrainian).

18. Makitra R., Pyrig J., Zagladko E., Turovskiy A., Zaikov G., J. Appl. Polym. Sci., 2001, 81, 3133.

19. Makitra R.G., Zagladko E.A., Turovskiy A.A., Zaikov G.E., J. Appl. Chem., 2004, 77, 1719 (in Russian).

20. Makitra R.G., Prystansky R.Y., Chem. of Solid Fuels, 2001, No. 5, 13 (in Russian).

21. Makitra R.G., Turovskiy A.A., Zaikov G.E. Correlation Analysis in Chemistry of Solutions. Utrecht-Boston, 2004, VSP, 320.

22. Makitra R.G., Prystansky R.Y., J. Appl. Chem., 2004, 77, 1419 (in Russian). 
23. Makitra R.G., Prystansky R.Y., Musiy R.Y., Yevchuk I.Y., Macromolecules B, 2005, 47, No. 1-2, 45-48.

24. Makitra R.G., Prystansky R.Y., Chem. of Solid Fuels, 2003, No. 4, 24 (in Russian).

25. Makitra R.G., Pyrig J.M., Chem. of Solid Fuels, 1993, No. 3, 14 (in Russian).

\title{
Трактування взаємодії полімерів з рідинами з точки зору принципу лінійності вільних енергій
}

\author{
Р.Макітра, І.Євчук, Р.Мусій \\ Фізико-хімічний факультет Інституту Литвиненка НАН України, \\ Львів 79053, вул. Наукова За
}

Отримано 6 липня 2005 р., в остаточному вигляді 17 жовтня 2005 р.

Існуючі теорії взаємодії між полімерами і рідинами не дають задовільного зв'язку між фізико-хімічними властивостями рідини і ступенем набрякання полімеру в системі полімер-рідина. Ми запропонували лінійне шестипараметрове рівняння, яке враховує як здатність рідини до специфічної і неспецифічної сольватації, так і енергію когезії і мольний об'єм. Це рівняння виявилось придатним для узагальнення даних таких процесів, як: дифузія рідин через тонкі плівки, розчинення полімерів, набрякання і екстракція вуглів.

Ключові слова: багатопараметричні рівняння, коефіцієнт кореляції, органічна рідина, полімер, сольватація, ступінь набрякання

PACS: $61.25 . H q, 61.82 . P v, 82.35 . L r$ 
